\title{
BARRIERS TO THE IMPLEMENTATION OF THE ADVANCED PRACTICE NURSING ROLE IN PRIMARY HEALTH CARE SETTINGS: AN INTEGRATIVE REVIEW
}

\author{
Maryam Fatemi (1) \\ Kathleen Benjamin (2) \\ Jessie Johnson (3) \\ Robin O’Dwyer (1) \\ (1) Primary Healthcare Corporation, Qatar \\ (2) Adjunct, Faculty of Nursing, University of Calgary, Canada \\ (3) Faculty of Nursing University of Calgary Qatar
}

\section{Corresponding author:}

Maryam FATEMI, BScN, MN,

Primary Healthcare Corporation,

Qatar

Email: mgfatemi@ucalgary.ca

Received: September 2020; Accepted: October 2020; Published: November 1, 2020

Citation: Maryam Fatemi et al. Barriers to the Implementation of the Advanced Practice Nursing Role in Primary Health Care Settings: An Integrative Review. Middle East Journal of Nursing 2020; 14(2): 16-37. DOI: 10.5742/MEJN2020.93794

\section{Abstract}

Background: Advanced practice nurses are nurses prepared with advanced clinical education, skills, and competencies required to assess, diagnose, treat and deliver continuous care for acute or chronic conditions. The move toward using advanced practice nurses in primary healthcare settings in Qatar is inevitable to advance the nurse's role, improve the level of services provided, raise patient satisfaction, and improve the organizational outcomes.

Aim: The aim of this review was to explore the barriers in implementing advanced practice nursing in primary health care settings in order to facilitate its implementation in Qatar.

Method: Whittemore and Knalf's framework guided this integrative review. Fourteen studies published between 2009 and 2019 were included in the review. The mixed-methods appraisal tool was used to assess the quality of the studies. The socio-ecological model was used to categorize and present barriers at the individual; organizational, social, cultural, policies, and environmental level.

Result: Three main barriers noted were a lack of clarity and support of the role, lack of organizational and policy support for the role, and a lack of designated space for APN practice.
Conclusion: Identifying and addressing barriers is necessary to achieve successful implementation of the APN role within primary healthcare in Qatar. Key recommendations for Qatar include integrating key stakeholders in the implementation process, use of a clear job description and policies, and providing designated workspaces for APN practice.

Key words: advanced practice nursing, clinical nurse specialist, nursing practitioners, primary health care, barriers 


\section{Introduction}

Over the past decade, there has been a fundamental development in nursing roles to meet the growing population demands for health care services and to improve the quality of services provided in $\mathrm{PHC}$ settings. The APN role is an innovation that is being implemented in most countries internationally. As mentioned by Sánchez-Gómez et al. (2019), the APN role was introduced in the United States in the 1970s. APNs have a high level of professional autonomy, advanced skills in health assessment, diagnosis, decision making, and research and are qualified to plan, implement, and evaluate health care programs (Sánchez-Gómez et al., 2019).

According to the Canadian Nurses' Association (CNA; 2008), the term APN has been used as an umbrella term signifying nurses practicing at a higher level by using their graduate educational preparation, knowledge, and skills to meet the health care needs of individuals, families, and communities. APN includes four different categories which are clinical nurse specialist (CNS), nurse practitioner (NP), certified nurse-midwife, and certified registered nurse anesthetic (Hamric et al., 2014). This paper will focus specifically on the barriers reported to the implementation of the CNS and NP roles within a primary health care setting.

The International Council of Nurses (ICN; n.d.) defines APN as a registered nurse who has acquired an expert knowledge base, complex decision-making skills and clinical competencies for expanded practice, the characteristics of which are shaped by the context and/ or country in which s/he is credentialed to practice. A master's degree is recommended for entry level (para. 2).

The state of Qatar aspires to follow a global statement that a strong primary health care is the foundation of an effective health system. In 1954, Qatar took its first steps in creating a primary health care system (PHCC, 2018a). In 1978, the Ministry of Health developed a program to build a PHC system which included initiation of PHC services through nine health centers across Qatar (PHCC, 2018a). In 2012, the Emiri Decree No.15 was issued to establish the primary health care corporation (PHCC) as an independent corporation (Hukoomi, 2019). Currently, there are 27 primary health centers in Qatar distributed into three regions: Central, Western, and Northern (PHCC, 2018a).

The APN role implementation is complex and requires prior planning in order to introduce the role and clarify the difference between their role and other professionals. Removing the barriers that prevent APNs from practicing to their full scope is very important to expand services of PHC and to make them more effective and efficient providers of care (Park et al., 2016).

\section{Method}

Whittemore and Knafl's (2005) integrative review framework was chosen to guide this review. The five stages of this framework are problem identification, literature search, data evaluation, data analysis, and presentation of the results.

\section{Stage 1: Problem Identification}

The first stage of the framework is a "clear identification of the problem" (Whittemore \& Knafl, 2005, p. 548). Thus, the focus of this paper was to identify possible barriers to implementation of the APN role and to consider these barriers in relation to the context of PHCC in Qatar.

\section{Stage 2: Literature Search}

The following data bases were searched: Cumulative Index to Nursing and Allied Health Literature (CINAHL), Pub Med, MEDLINE, and Academic Search Complete. The key search terms were advance nursing practice, advanced practice nurse*, clinical nurse specialist*, nurse practitioner*, nursing role, scope of practice, role implementation*, primary health*, and community care*. The Boolean operators AND and OR were used to combine or broaden the search. Inclusion criteria were: of (a) primary studies, (b) qualitative, quantitative, and mixed studies, (c) published in English, (d) studies published from 2009- 2019, (e) studies that focused on CNS and NP, (f) studies conducted in primary care settings, and $(\mathrm{g})$ studies focused on the challenges and barriers of implementing the APN role implementation. See Figure 1 for literature search flow diagram.

\section{Stage 3: Data Evaluation}

The Mixed Methods Appraisal Tool (MMAT) was used to assess the quality of studies in this review. The MMAT was developed in 2006 (Pluye et al., 2011) and has been applied in other literature reviews (e.g., Benjamin \& Donnelly, 2013; Gowing et al., 2017; Scott et al., 2019). It is a useful tool because it can assess the methodological quality of different types of research designs, including qualitative, quantitative descriptive studies, quantitative randomized controlled trial, quantitative non-randomized studies, and mixed methods studies.

The two main steps in the MMAT are: (1) answering two general screening questions for any type of study, which must be answered with "yes" to advance to the second step of the appraisal tool and (2) answering five questions specific to the study design. Response options are yes, no, and cannot tell. Unlike the original tool which used a scoring system with possible value of $25 \%$ to $100 \%$ (Pluye et al., 2011) the revised 2018 tool does not use a scoring system, and step two includes five rather than four questions (Hong et al., 2018). The appraisal found that the eight qualitative studies and one quantitative study met all of the five criteria. One mixed methods study and four quantitative studies meet four of the five criteria. 
Figure 1: Literature Search Flow Diagram

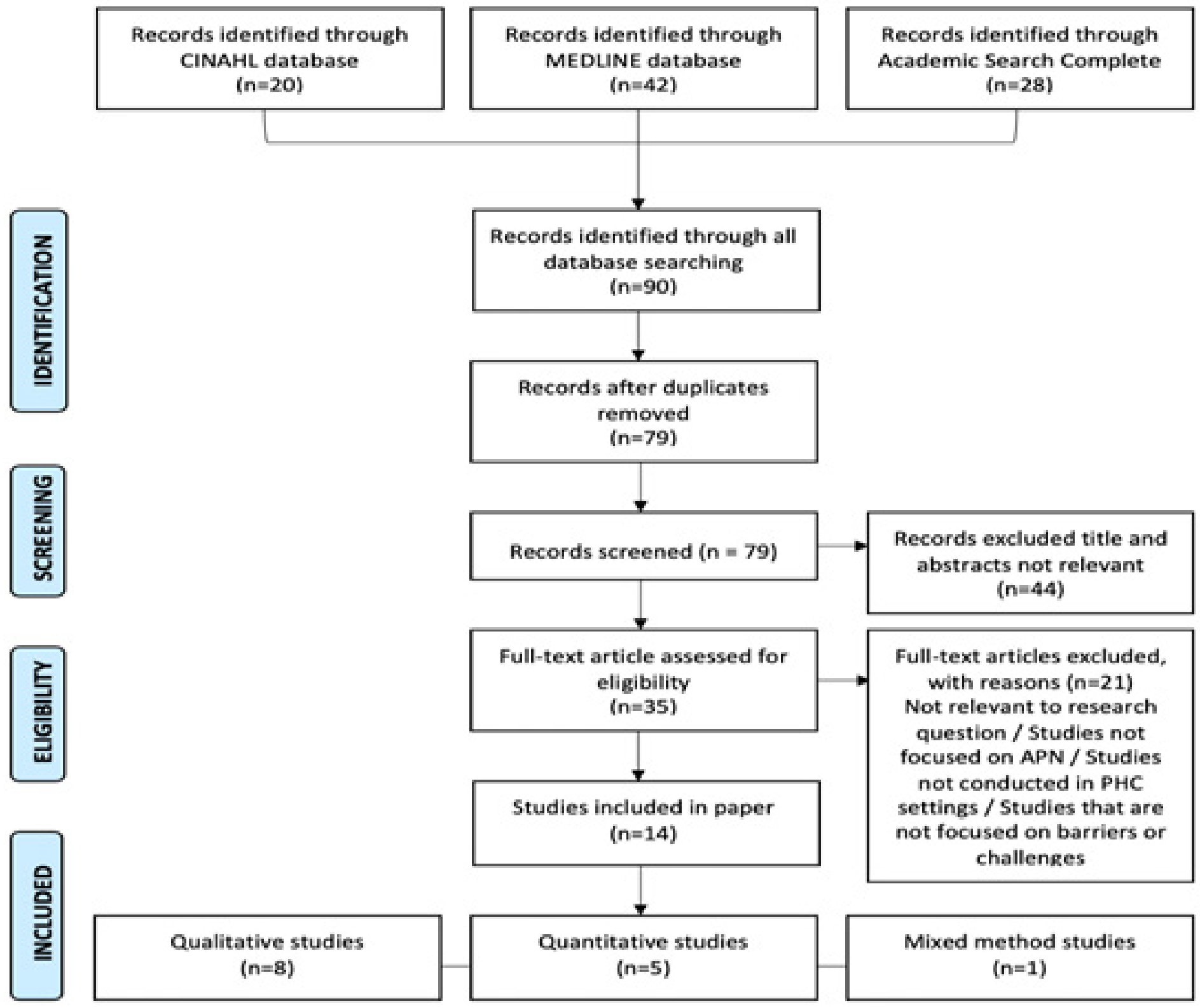




\section{Stage 4: Data Analysis}

Data analysis involves the following processes: data reduction, data display, data comparison, conclusion drawing and verification (Whittemore \& Knafl, 2005). In the data reduction phase, data from diverse methodologies are classified which can be based on the type of evidence, or chronology, or sample characteristics, or predetermined conceptual classification (Whittemore \& Knafl, 2005). Data reduction includes techniques of coding the extracted data, which provides organized and concise information of the literature in a matrix or spreadsheet (Whittemore \& Knafl, 2005). The organization of data into a manageable structure (e. g. matrix or tables) facilitates the comparison of the primary resources on specific variables, such as sample characteristics (Whittemore \& Knafl, 2005). Extraction tables were developed for this review to summarize the information from the 14 articles and to arrange the recognized barriers under certain categories and codes (see Appendix A).

In the data display phase, the extracted data is converted into visuals such as graphs, matrices, charts, or networks and placed around a particular variable (Whittemore \& Knafl, 2005). Figure 2 illustrates a diagram to show the barriers extracted from the 14 articles.

\section{Figure 2: Barriers to the Implementation of the APN Role across the 14 Articles}

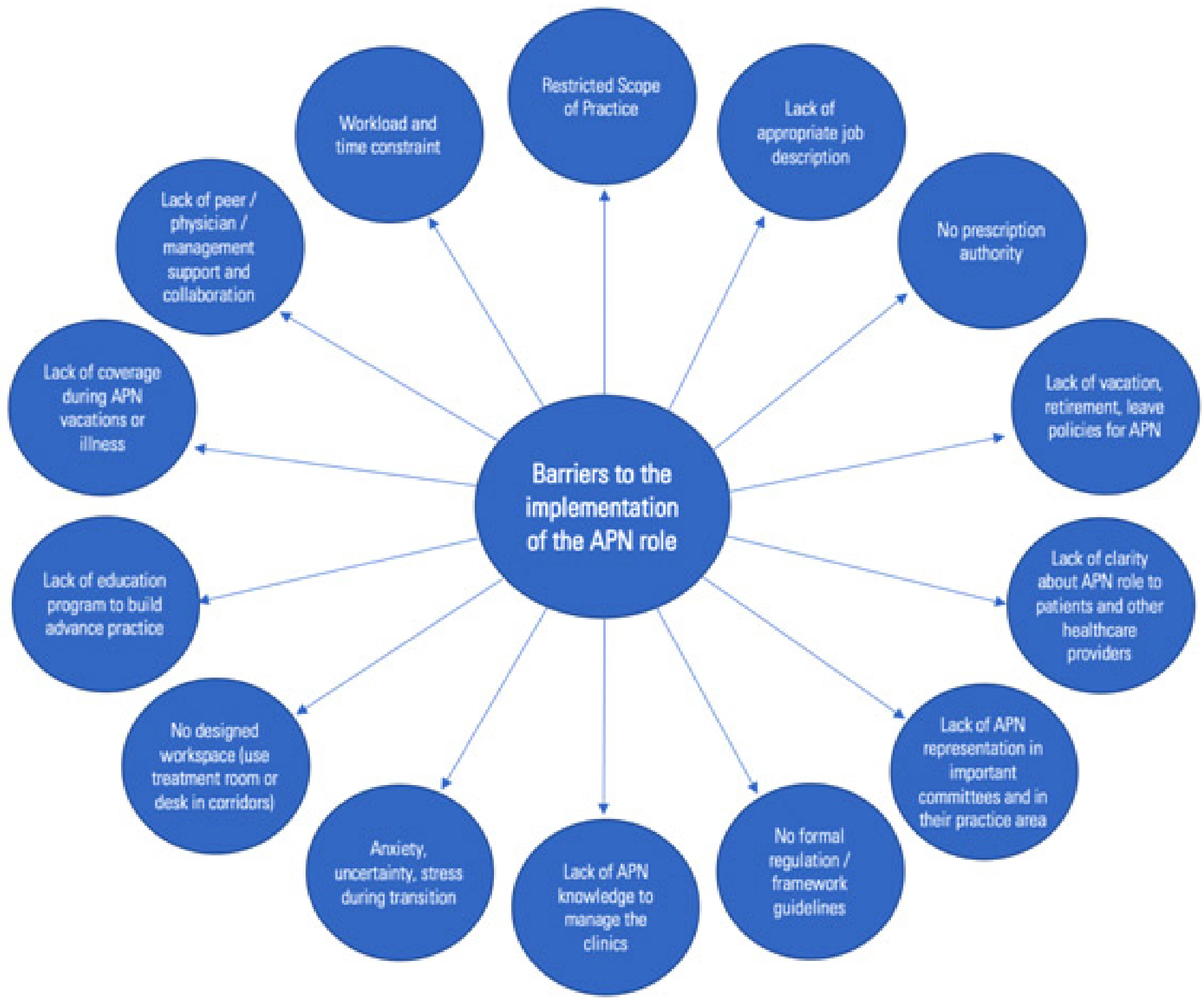


In the data comparison phase, the data is frequently examined to identify themes, relationships or patterns (Whittemore \& Knafl, 2005). In this phase, the SocioEcological Model (SEM) guided the authors thinking about the barriers, as well as the organization and presentation of these barriers. This model helps researchers to identify factors that may affect behaviors by looking beyond the individual level (e.g. organizational, policy, cultural or environmental level; Golden et al., 2015). Thus, the SEM was used to examine and describe the dynamic relationship among barriers at the individual, organizational, social, and cultural and policy, and environmental levels see Figure 3.

Figure 3: Barriers Categorized at Three Main Levels of the Socio-Ecological Model

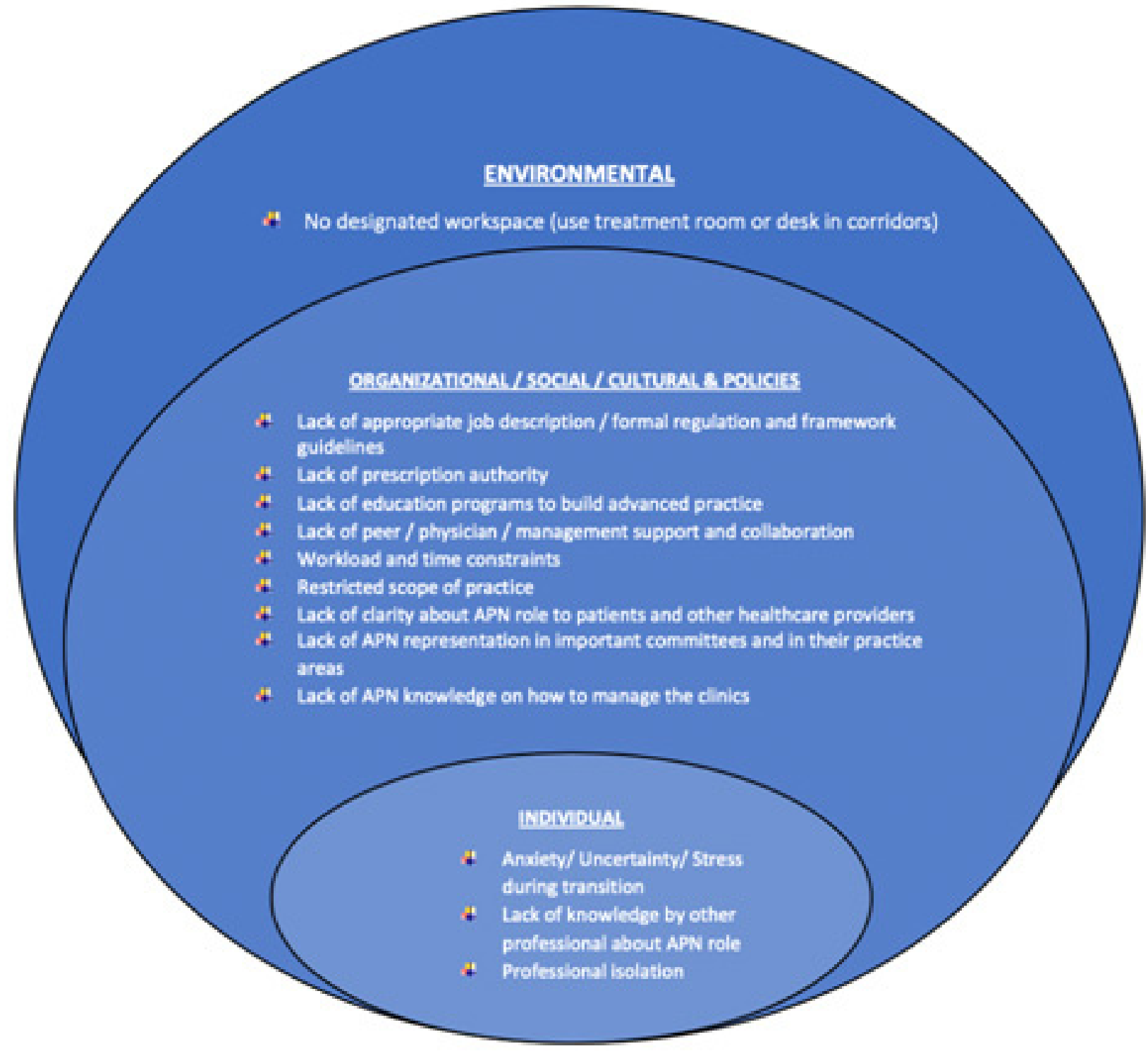


In the conclusion drawing and verification phase, the researcher completes the review process through identification of similarities and differences of the information, and integration of all subgroups into an inclusive description of the topic concerns (Whittemore \&
Knafl, 2005). The three main themes that emerged from the data were: the APN role was poorly understood and not supported, there was a lack of organizational and policy support, and a lack of designated workspace for APN (see Figure 4).

\section{Figure 4: The Major Themes at Each Level of the Socio-Ecological Model}

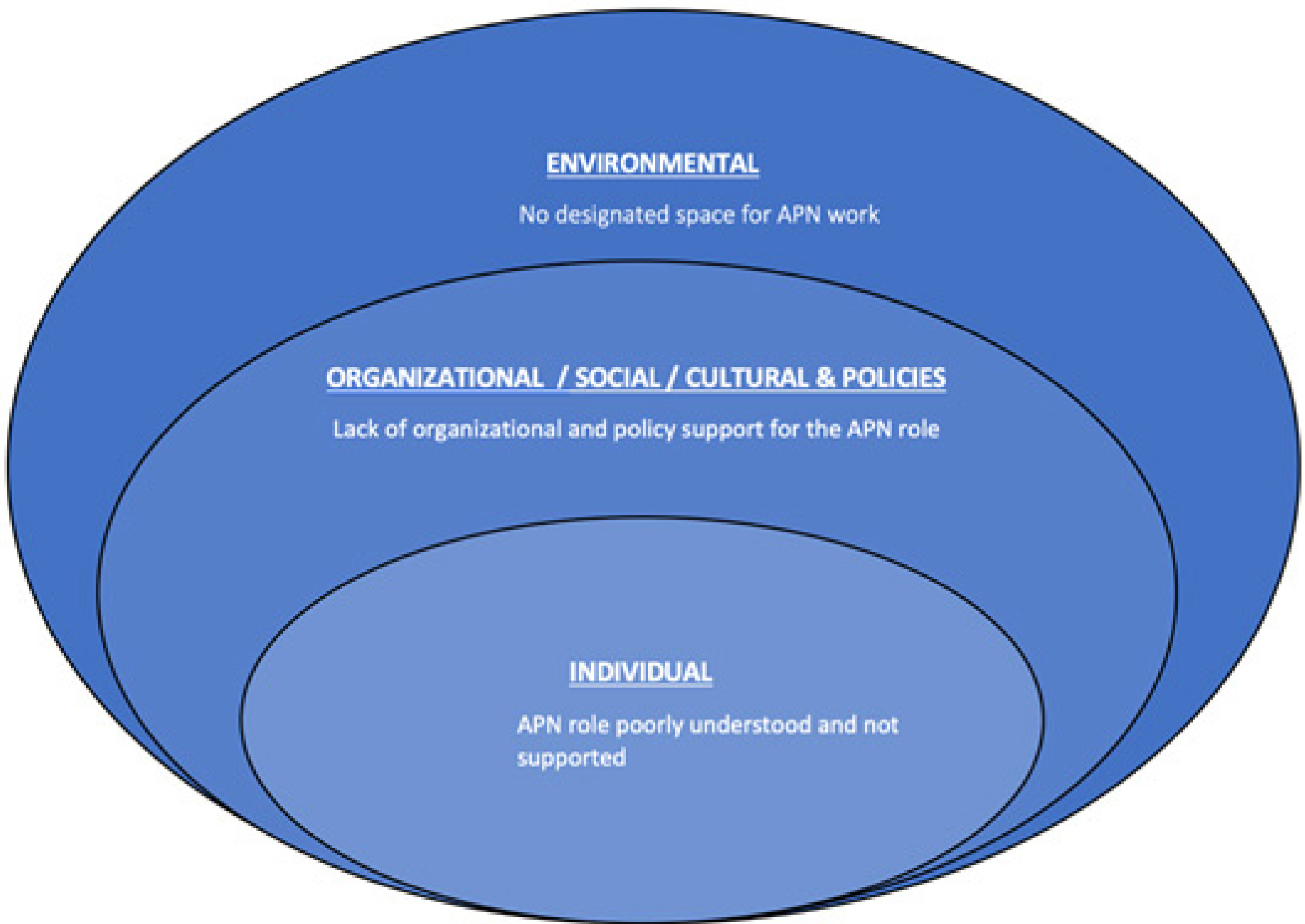

\section{Stage 5: Presentation of the Results}

According to Whittemore and Knafl (2005), this phase aims to reach a new understanding of the phenomenon by capturing the depth and clarity of the results.

\section{Characteristics of the Study}

The 14 retained studies published between 2009 and 2019 were primary resources including three research approaches, (i.e. quantitative, qualitative and mixed method studies were conducted in the following countries, USA ( $n=8)$, and one in each of the following countries: Norway, Australia, Canada, Bahrain, and Netherlands. There were eight qualitative studies (i.e. two descriptive, one exploratory, one descriptive exploratory, one ground theory, one ethnography, one narrative inquiry, and one qualitative study nested in a RCT). There were five quantitative studies, four were cross sectional descriptive studies and one quasi-experimental design. The primary focus of each study is discussed below.
In the descriptive studies, Poghosyan et al. (2013) investigated NPs role and responsibilities as primary care providers and their perception about barriers and facilitators to their scope of practice. Poghosyan et al. (2018) assessed the perspectives of physicians and APNs regarding the barriers and facilitators related to the implementation of the APN role. In the descriptive, Henni et al. (2018) described the experience of nurses in their new role as advanced geriatric nurses and discussed what strategies the nurses considered important in the development of their new role. McKenna et al. (2015) explored key stakeholder's perspectives of the barriers and enablers influencing the development of APN role in primary care. In the grounded theory study, Kraus and Dubois (2016) explored the attitudes of NP and physicians related to the independent practice of NP. In an ethnographic study, Sharp and Monsivais (2014) described rural NP perceived difficulties related to the business-related aspects of practice. In a narrative study, Hernandez and Anderson (2011) explored the 
NP experiences caring for pre-hypertensive patients. In a nested study Voogd- Pruis et al. (2011) examined the experiences, barriers, and facilitators of eight NPs related to the implementation of a nurse-delivered cardiovascular prevention program in primary care.

Regarding the quantitative studies, 2 studies examined job satisfaction among APN in developing countries and identified the barriers and facilitators associated with APN role implementation (Guzman et al., 2010; Steinke et al., 2017). Poghosyan and Aiken's (2015) study aimed to better understand the NP role and organizational characteristics important for NP practice in primary care. Poghosyan et al. (2017), examined and compared the NP patient panel, job satisfaction, turnover, and organizational structure within the employment settings of NP with less than three years with more than three years of NP experience. In a quasi-experimental study, Nasaif (2012) examined the knowledge and attitudes of primary care physicians about NP role pre and post an educational intervention.

There was one mixed method study of Chapman et al. (2018). In the qualitative component, semi-structured interviews were conducted to identify barriers to full utilization of Psychiatric Mental Health Nurse Practitioners (PMHNPs). In the quantitative component, PMHNPs' economic contribution in the public behavioral health systems were assessed.

The SEM was used to guide this literature review. It allows a person to see factors that influence behavior at several layers of a system that goes beyond the individual level only (Golden et al., 2015). Using the SEM, barriers were categorized at three different levels of the model: the individual; the social, cultural, and policy; and the environmental level.

\section{Barriers at the Individual Level}

The individual level involves the individual's knowledge, perceptions, beliefs, and attitudes which is influenced by his/her social and physical environments (Salihu et al., 2015). Several articles revealed that physicians and other healthcare professionals lacked knowledge about the APN's scope of practice, did not accept the APN role or did not allow them to work to their full scope of practice (Guzman et al., 2010; Kraus \& Dubois, 2016; Nasif, 2012; Poghosyan et al., 2013; Poghosyan et al., 2017; VoogdtPruis et al., 2011).

In a study by Poghosyan et al. (2017), the majority of APNs felt that they were not treated equally to physicians in their workplace. Two articles mentioned that professionals did not support APNs because they felt threatened by the emerging role (Guzman et al., 2010; Steinke et al., 2017). Guzman et al. (2010) reported that the most frequent barriers mentioned by NPs were lack of respect from the physicians and an unwillingness of specialists to accept referrals from NPs. A theme that emerged in Guzman et al.'s (2010) study was professional isolation. APN felt isolated from other staff and they did not feel that they were a part of the healthcare team. Barriers reported in other studies included feelings of uncertainty, anxiety and stress during transition to the NP role (Guzman et al., 2010; Sharp \& Monsivais, 2014; Voogdt-Pruis et al., 2011). APNs felt overwhelmed by the demands of their role, and felt they lacked the skills and knowledge on how to manage clinics. They also experienced role conflict between taking care of patients versus managing their clinics (Guzman et al., 2010; Sharp \& Monsivais, 2014), and a disconnect between actual practice and the practice model used in schools (Hernandez \& Anderson, 2011). In this review, the overarching theme that emerged at the individual level was that the APN role was poorly understood and unsupported.

\section{Barriers at the Social, Cultural, and Policy Level}

The SEM facilitates examination of political and social environments of healthcare structures that are not independent from each other to better understand a person's health or behavior (Reifsnider et al., 2005). Poghosyan et al. (2018), reported that stagnant organizational policies were less supportive to expand the NP scope of practice. and both physicians and NP reported that their organization does not keep them informed about the state policy change (Poghosyan et al., 2018). McKenna et al.'s (2015) revealed that there were practice limitations for APNs which included lack of support from management, lack of encouragement for nurses to work to their full scope of practice, and an organizational emphasis on a business model rather than nursing services as well as lack of access and funding for educational and professional development for APNs.

Poghosyan et al. (2013), reported several barriers such as lack of NP patient panel, lack of access to medical organizational supports, no representation of NP in decision making committees, and lack of organizational structure to promote NP's scope of practice. Similar themes were identified in Poghosyan and Aiken's (2015) study: lack of clarity of NP role, lack of NP representation in important committees, and lack of communication between NP and administrators. Almost half of the NPs in Poghosyan et al.'s (2017) study reported that NPs are not represented in important committees within their organization, and both newly hired and experienced NPs reported significant challenges in their relationship with administrators. They reported that administrators did not treat them equally compared to other providers and did not share organizational resources equally with them (Poghosyan et al., 2017). In Hernandez and Anderson's (2011) study, NPs reported that the daily pressure of a tight schedule, double booking of patients, and coordinating care led to a sense of "surviving the day" (p. 93). In this study, time constraints and lack of public support for health promotion activities were identified as a barrier for NPs. Barriers identified in Voogdt-Pruis et al.'s (2011) study included limited patient recording and computer systems, lack of NP's ability to document special circumstances 
or treatments, and an unclear communication channel between NP and other healthcare providers.

Henni et al. (2018), described that participants found it difficult to develop an APN role because there were no formal regulations, frameworks, or guidelines. Sharp and Monsivais's (2014) study reported that NPs were underutilized because of the state nursing act, for instance; some states permit NPs to practice independently, while other states require the supervision or collaboration of a physician. In Kraus and Dubois's (2016) study, NPs reported that arbitrary laws and practice restrictions were unreasonable for safe and effective care. Furthermore, the study reported that physicians' focus on NP independence was very patient-oriented and not selfpromoting or defiant. Laws in USA did not optimize NP's ability to provide the care that they saw as part of their scope of practice (Kraus \& Dubois, 2016).

In Steinke et al.'s (2017) study, NPs reported that the key barriers for them were lack of respect from supervisors and physicians, increase in administrative tasks and workload, lack of vacation pay, and inadequate retirement and leave policies. Barriers reported by Chapman et al. (2018) included lack of an appropriate job description, lack of job offerings for the NP role, lengthy hiring process, and restricted scope of practice for NPs. In Guzman et al.'s (2010) study, barriers reported were: being the only NP working in the unit (39.2\%), inadequate salaries (32.1\%), lack of the employers' knowledge about the NP role $(32.1 \%)$, lack of employer support for NP $(21.4 \%)$, inadequate clerical support $(14.2 \%)$, lack of NP coverage during sick leave or vacation (10.7\%), lack of NP involvement in role development $(7.1 \%)$, and not being consulted by other staff members (3.6\%). In this review, the overarching theme that emerged at the social, cultural, and policy level were lack of job description, policy, and organizational support for the APN role.

\section{Barriers at the Environmental Level}

The SEM assumes that there is a mutual interaction between individuals and their environment, which implies that a person is affected by his or her environment and vice versa (Salihu et al., 2015). Only two studies included barriers about the physical environment (McKenna et al., 2015; Voogdt-Pruis et al., 2011). In both studies, participants reported that a lack of physical space acted as a barrier. For instance, there was no designated space for APNs, and they frequently had to use treatment rooms or a desk in corridors. In this review, the overarching theme reported at the environmental level was no designated space for APN work.

\section{Discussion}

This integrative review identified barriers faced by APNs internationally during the implementation of the APN role, aiming to consider the potential relevance of these barriers to the context of Qatar. Barriers were categorized at the individual level, organizational level and environmental level.

\section{Individual Level}

This review reported that the APN role was poorly understood and unsupported. Similar ideas have been reported in other literature. According to Behrens (2018), for those countries not familiar with the history or scope of the APN role, it is important to explain and share the vision of the role in a way that makes it accepted and welcomed by the culture. Despite the great need for APN, healthcare organizations still lack information on how to use this role, how to facilitate APN employment, and how to benefit from their qualifications (Bryant-Lukosius \& Dicenso, 2004). Confusion and conflict around the APN role are significant barriers to APN role incorporation and practice. As mentioned in Gysin et al.'s (2019) study, APNs and general practitioners agreed that the APN role is not fully defined nor well known especially in primary care settings. The introduction of the APN role in PHCC will be completely new, which means that the scope of this new role is unknown to healthcare professionals in Qatar.

Another common barrier related to lack of understanding of the APN role was resistance to change that engendered a lack of support for the role. APN's role contains many complexities that require prior planning for introduction, mentorship, and consideration of the overlap between APN and other professions. According to Sangster-Gormley et al. (2011), the lack of clarity and knowledge about the APN role may lead to resistance to its implementation by other professions. As mentioned by Jokiniemi et al. (2014), physicians can be challengers for the role implementation because they believe that APN would subsume some their professional role and responsibilities. Several participants in Casey et al.'s (2018) study reported that the physicians felt APN were invading their zone. The main reasons for physician resistance to the role implementation was the potential overlap in the scope of practice between physicians and APNs working in primary healthcare settings (Fougere et al., 2016). As mentioned by Mboineki et al. (2018), the lack of physician's awareness and knowledge about the APN role created stress among the APNs. Therefore, the physician's unawareness about the APNs can be one of the key barriers to implementing the role within any healthcare organization. Within the context of PHCC, the main members of healthcare are physicians, nurses, and pharmacists. Thus, implementing the APN role differs from the regular nursing role. As the APN is a relatively new role in the Qatari healthcare system, it is essential that physicians have the required knowledge about the role, such as APNs function, scope of practice, and competencies. 
To ensure successful implementation of the APN role, a mixture of stakeholders must be involved such as policy makers, medical professionals and health service managers (Behrens, 2018; Gysin et al., 2019; Oldenburger et al., 2017). Their engagement will contribute to a better understanding of the APN role, which will facilitate the acceptance, recognition and respect of the role to help reach successful implementation (Behrens, 2018; Gysin et al., 2019; Oldenburger et al., 2017). According to BryantLukosius and Dicenso (2004), determining and engaging key stakeholders is very important in the process of developing an APN's role, which can help to define the role of the APN, detect common goals, and identify the requirements of this role within the organization.

The barriers can be converted to facilitate the role implementation by increasing the awareness among physicians to consider APN as a part of their team and not a competitor (Jokiniemi et al., 2014). Clarifying the APN role can help considerably in minimizing the resistance of the role implementation in healthcare organizations. As mentioned in Gysin et al. (2019), physicians confirmed that they were not aware of what is an APN and what they can do in order to cooperate with APNs at work. Therefore, it is important to understand the doctors' knowledge and attitude about APN in PHCC in Qatar because they are the key in helping to facilitate the implementation of the APN role in primary care settings.

\section{Organizational, Social, Cultural, and Policy Level}

The main theme that emerged at the organizational, social, cultural, and policy level was lack of organizational and policy support for the APN role. This has several implications for practice and policy. According to Heale and Buckley (2015), the lack of regulation and title protection of the advanced nursing practice is identified as a barrier to the implementation of the APN role. In an integrative review paper by Sangster-Gormley et al. (2011), barriers to implementing the role of APNs exist at the organizational level such as the absence of standard job description and lack of human resource planning which leads to incompetence to practice within the full scope of the APN. At the same time, having a job description can facilitate the presence of settings where relationships are recognized, roles are clear, and work patterns are detailed for APNs (Sangster-Gormley et al., 2011). To ensure securing the APN role, the organization must include a strong evidence-based practice about APN procedures and practices, building a national policy with central stockholders (Jokiniemi et al., 2014). The job description provides a strong regulation of professional legislation which offers health professionals legality through credentialing procedures such as licensure, registration and certification, and authorized clinical tasks (Heale \& Buckley, 2015). According to Kooienga and Carryer (2015), efficient health outcomes and easy access to health services have improved dramatically in many countries after introducing APN who have clear authority and laws to implement his or her job comprehensively and effectively.
Lack of job description, policy and framework in the plan of PHCC to implement the APN role must be addressed. Currently in Qatar, there is no job description for the APN role within the $\mathrm{PHCC}$ in. To introduce the role of the ANP within the PHCC services, a clear job description, and framework structure should be in place to facilitate the role implementation of the APN. Through the APN's job description, PHCC can construct a practice regulatory model that includes the job titles and specialties, the educational requirements, the scope of practice, and the potential field of work within the institution. PHCC needs an accurate and functional job description for APNs to give directions and guidance for developing, implementing, and evaluating APNs roles. The PHCC can modify an existing international job description in order to create a tailored job description for APNs based on the needs of the population. A job description sets clear expectations at the outset of their employment about what is expected of them in line with the requirements of the community and PHCC needs in Qatar.

\section{Environmental Level}

The main theme that emerged was no designated space for APN work. Providing the required physical space is important to facilitate APN's to practice to their full scope of practice which may ensure better patient care in the organization. As mentioned in Sangster-Gormley et al.'s (2013) study, the APNs reported that they could not practice their role until a designated work place was available for them, According to Donelan et al. (2013), most of the study participants agreed that the lack of physical work place was the key factor in limiting the APNs' scope of practice. The APN role does not yet exist in PHCC in Qatar, which means that the healthcare center buildings may not able to provide a designated work spaces for the APNs. Having a designated workplace for the APNs is crucial to facilitate communication and collaboration with the healthcare team (Schadewaldt et al., 2016).

\section{Limitations}

Studies included in this review were limited to studies published in English; therefore, other relevant studies in other languages were excluded. Only one Middle Eastern study conducted in Bahrain in 2012 was identified which creates a gap in our knowledge.

\section{Conclusion}

This integrative review aimed to identify the barriers to the implementation of the APN role internationally and to consider their relevance within the context of $\mathrm{PHCC}$ in Qatar. APNs have the scientific background and skills required to deal with complex health problems among Qatar's population. To ensure effective implementation of the APN role, barriers must be identified and addressed. The main barriers in this review were a lack of understanding and support for the APN role, lack of a job description, policy, and organizational support for the APN role, and no designated space for APN's practice. 
Key recommendations for Qatar include: engage all key stakeholders' in the implementation process, create a clear job description and precise framework for APN and, provide a designated work space for APN's within PHCC. By minimizing the barriers to role implementation, $\mathrm{PHCC}$ will benefit from the full utilization of the APNs skills and knowledge while tailoring their practice to the community's requirements in Qatar.

\section{References}

Behrens, S. A. (2018). International nursing: Constructing an advanced practice registered nurse practice model in the UAE: Using innovation to address cultural implications and challenges in an international enterprise. Nursing Administration Quarterly, 42(1), 83-90. https://doi. org/10.1097/NAQ.0000000000000273

Benjamin, K., \& Donnelly, T. (2013). Barriers and facilitators influencing the physical activity of Arabic adults: A literature review. Avicenna, (2013), 8. https://doi. org/10.5339/avi.2013.8

Bryant-Lukosius, D., \& DiCenso, A. (2004). A framework for the introduction and evaluation of advanced practice nursing roles. Journal of Advanced Nursing, 48(5), 530540. https://doi.org/10.1111/j.1365-2648.2004.03235.x

Canadian Nurses Association. (2008). Advanced nursing practice: A national framework. https://www.cna-aiic. ca/en/ /media/nurseone/page-content/pdf-en/anp_

national_framework_e

Casey, M., O'Connor, L., Cashin, A., Fealy, G., Smith, R., O'Brien, D., Stokes, D., McNamara, M., O'Leary, D. \& Glasgow, M. E. (2018). Enablers and challenges to advanced nursing and midwifery practice roles. Journal of Nursing Management, 27(2), 271-277. https://doi. org/10.1111/jonm.12697

Chapman, S. A., Phoenix, B. J., Hahn, T. E., \& Strod, D. C. (2018). Utilization and economic contribution of psychiatric mental health nurse practitioners in public behavioral health services. American Journal of Preventive Medicine, 54(6). https://doi.org/10.1016/j.amepre.2018.01.045

Donelan, K., DesRoches, C. M., Dittus, R. S., \& Buerhaus, P. (2013). Perspectives of physicians and nurse practitioners on primary care practice. New England Journal of Medicine, 368(20), 1898-1906. https://doi. org/10.1056/nejmsa1212938

Fougère, B., Morley, J. E., Decavel, F., Nourhashémi, F., Abele, P., Resnick, B., Rantz, M., Lai, C. K. Y., Moyle, W., Pédra, M., Chicoulaa, B., Escourrou, E., Oustric, S., \& Vellas, B. (2016). Development and implementation of the advanced practice nurse worldwide with an interest in geriatric care. Journal of the American Medical Directors Association, 17(9), 782-788. https://doi.org/10.1016/ j.jamda.2016.05.009

Golden, S. D., McLeroy, K. R., Green, L. W., Earp, J. A. L., \& Lieberman, L. D. (2015). Upending the social ecological model to guide health promotion efforts toward policy and environmental change. Health Education \& Behaviour, 42(1), 8S-14S. https://doi.org/10.1177/109019811557509
Gowing, J. R., Walker, K. N., Elmer, S. L., \& Cummings, E. A. (2017). Disaster preparedness among health professionals and support staff: What is effective? An integrative literature review. Prehospital and Disaster Medicine, 32(3), 321-328. https://doi.org/10.1017/ s1049023x1700019x

Guzman, A., Ciliska, D., \& DiCenso, A. (2010). Nurse practitioner role implementation in Ontario public health units. Canadian Journal of Public Health, 101(4), 309313. https://doi.org/10.1007/bf03405292

Gysin, S., Sottas, B., Odermatt, M., \& Essig, S. (2019). Advanced practice nurses' and general practitioners' first experiences with introducing the advanced practice nurse role to Swiss primary care: a qualitative study. BMC Family Practice, 20(1), 1-11. https://doi.org/10.1186/s12875-0191055-z

Hamric, A. B., Hanson, C. M., Tracy, M. F., \& O'Grady, E. T. (2014). Advanced practice nursing: An integrative approach (5th ed.). Elsevier Health Sciences.

Heale, R., \& Rieck Buckley, C. (2015). An international perspective of advanced practice nursing regulation. International Nursing Review, 62(3), 421-429. https://doi. org/10.1111/inr.12193

Henni, S. H., Kirkevold, M., Antypas, K., \& Foss, C. (2018). The role of advanced geriatric nurses in Norway: A descriptive exploratory study. International Journal of Older People Nursing, 13(3). https://doi.org/10.1111/ opn.12188

Hernandez, J., \& Anderson, S. (2011). Storied experiences of nurse practitioners managing prehypertension in primary care. Journal of the American Academy of Nurse Practitioners, 24(2), 89-96. https://doi.org/10.1111/j.17457599.2011.00663.x

Hong, Q. N., Gonzalez-Reyes, A., \& Pluye, P. (2018). Improving the usefulness of a tool for appraising the quality of qualitative, quantitative and mixed methods studies, the mixed methods appraisal tool (MMAT). Journal of Evaluation in Clinical Practice, 24(3), 459-467. https://doi. org/10.1111/jep.12884

Hukoomi. (2019). Primary health care. https://portal.www. gov.qa/wps/portal/topics/Health/ primaryhealthcare

International Council of Nurses. (n.d.). Nurse practitioner and advanced practice nursing. http://international.aanp. org/practice/APNRoles

Jokiniemi , K., Haatainen, K., Meretoja, R., \& Pietilä, A.-M. (2014). Advanced practice nursing roles: The phases of the successful role implementation process. International Journal of Caring Sciences, 7(3), 946-954. https://www. semanticscholar.org/paper/Advanced-Practice-NursingRoles\%3A-The-Phases-of-the-Rn-Kaisa/ 6aa02cb52a8e 15258a85dcb971db1d2aa6c4b47c

Kooienga, S. A., \& Carryer, J. B. (2015). Globalization and advancing primary health care nurse practitioner practice. The Journal for Nurse Practitioners, 11(8), 804-811. https://doi.org/10.1016/j.nurpra.2015.06.012 
Kraus, E., \& Dubois, J. M. (2016). Knowing your limits: A qualitative study of physician and nurse practitioner perspectives on NP independence in primary care. Journal of General Internal Medicine, 32(3), 284-290. https://doi. org/10.1007/s11606-016-3896-7

Mboineki, J. F., Changying, C., \& Zhang, W. (2018). Health care providers perceptions regarding fundamental issues to consider prior to launching nurse practitioner training in Tanzania. Journal of the American Association of Nurse Practitioners, 30(11), 621-629. https://doi.org/10.1097/ jxx.0000000000000085

Mckenna, L., Halcomb, E., Lane, R., Zwar, N., \& Russell, G. (2015). An investigation of barriers and enablers to advanced nursing roles in Australian general practice. Collegian, 22(2), 183-189. https://doi.org/10.1016/ j.colegn.2015.02.003

Nasaif, H. A. (2012). Knowledge and attitudes of primary care physicians toward the nurse practitioner role in the Kingdom of Bahrain. Journal of the American Academy of Nurse Practitioners, 24(3), 124-131. https://doi.org/10.1111/ j.1745-7599.2011.00710.x

Oldenburger, D., Cassiani, S. H. D. B., Bryant-Lukosius, D., Valaitis, R. K., Baumann, A., Pulcini, J., \& Martin-Misener, R. (2017). Implementation strategy for advanced practice nursing in primary health care in Latin America and the Caribbean. Revista Panamericana de Salud Pública, 41, 1. https://doi.org/10.26633/rpsp. 2017.40

Park, J., Athey, E., Pericak, A., Pulcini, J., \& Greene, J. (2016). To what extent are state scope of practice laws related to nurse practitioners' day-to-day practice autonomy? Medical Care Research and Review, 75(1), 66-87. https://doi.org/10.1177/1077558716677826

Pluye, P., Robert, E., Cargo, M., Bartlett, G., O'Cathain A., Griffiths, F., Boardman, F., Gagnon, M.P., \& Rousseau M.C. (2011). Proposal: A mixed methods appraisal tool for systematic mixed studies reviews. https://www. scienceopen.com/document?vid $=$ feb74b8c-08fd $-4 b 8 c-$ ad08-65f7c2b8108e

Poghosyan, L., \& Aiken, L. H. (2015). Maximizing nurse practitioners' contributions to primary care through organizational changes. Journal of Ambulatory Care Management, 38(2), 109-117. https://doi.org/10.1097/ jac.0000000000000054

Poghosyan, L., Nannini, A., Smaldone, A., Clarke, S., O'Rourke, N. C., Rosato, B. G., \& Berkowitz, B. (2013) Revisiting scope of practice facilitators and barriers for primary care nurse practitioners. Policy, Politics, \& Nursing Practice, 14(1), 6-15. https://doi.org/10.1177/15271544134 80889

Poghosyan, L., Norful, A. A., \& Laugesen, M. J. (2018). Removing restrictions on nurse practitioners scope of practice in New York State. Journal of the American Association of Nurse Practitioners, 30(6), 354-360. https:// doi.org/10.1097/jxx.0000000000000040

Poghosyan, L., Norful, A. A., \& Martsolf, G. R. (2017) Organizational structures and outcomes of newly hired and experienced nurse practitioners in New York State. Nursing Outlook, 65(5), 607-614. https://doi.org/10.1016/ j.outlook.2017.03.001

Primary Health Care Corporation. (2018a). Corporate profile. https://www.phcc.qa/portal new/index/index. php?limit=profile

Reifsnider, E., Gallagher, M., \& Forgione, B. (2005). Using ecological models in research on health disparities. Journal of Professional Nursing, 21(4), 216-222. https:// doi.org/10.1016/j.profnurs.2005.05.006
Salihu, H. M., Wilson, R. E., King, L. M., Marty, P. J., \& Whiteman, V. E. (2015). Socio-ecological model as a framework for overcoming barriers and challenges in randomized control trials in minority and underserved communities. International Journal of $\mathrm{MCH}$ and AIDS (IJMA), 3(1), 85-95. https://doi.org/10.21106/ijma.42

Sánchez-Gómez, M., Ramos-Santana, S., GómezSalgado, J., Sánchez-Nicolás, F., Moreno-Garriga, C., \& Duarte-Clíments, G. (2019). Benefits of advanced practice nursing for its expansion in the Spanish context. International Journal of Environmental Research and Public Health, 16(5), 680. https://doi.org/10.3390/ ijerph16050680

Sangster-Gormley, E., Martin-Misener, R., \& Burge, F. (2013). A case study of nurse practitioner role implementation in primary care: what happens when new roles are introduced? BMC Nursing, 12(1). https://doi. org/10.1186/1472-6955-12-1

Sangster-Gormley, E., Martin-Misener, R., DowneWamboldt, B., \& DiCenso, A. (2011). Factors affecting nurse practitioner role implementation in Canadian practice settings: an integrative review. Journal of Advanced Nursing, 67(6), 1178-1190. https://doi-org.ezproxy.lib. ucalgary.ca/10.1111/j.1365-2648.2010.05571.x

Schadewaldt, V., Mclnnes, E., Hiller, J. E., \& Gardner, A. (2016). Experiences of nurse practitioners and medical practitioners working in collaborative practice models in primary healthcare in Australia - a multiple case study using mixed methods. BMC Family Practice, 17(1). https:// doi.org/10.1186/s12875-016-0503-2

Scott, S. D., Rotter, T., Flynn, R., Brooks, H. M., Plesuk, T., Bannar-Martin, K. H., Chambers, T., \& Hartling, L. (2019). Systematic review of the use of process evaluations in knowledge translation research. Systematic Reviews, 8(1). https://doi.org/10.1186/s13643-019-1161-y

Sharp, D. B., \& Monsivais, D. (2014). Decreasing barriers for nurse practitioner social entrepreneurship. Journal of the American Association of Nurse Practitioners, 26(10), 562566. https://doi-org.ezproxy.lib.ucalgary.ca/10.1002/23276924.12126

Steinke, M., Rogers, M., Lehwaldt, D., \& Lamarche, K. (2017). An examination of advanced practice nurses' job satisfaction internationally. International Nursing Review, $65(2)$, 162-172. https://doi-org.ezproxy.lib.ucalgary. ca/10.1111/inr.12389

Voogdt-Pruis, H. R., Beusmans, G. H., Gorgels, A. P. \& Ree, J. W. (2011). Experiences of doctors and nurses implementing nurse-delivered cardiovascular prevention in primary care: A qualitative study. Journal of Advanced Nursing, 67(8), 1758-1766. https://onlinelibrary-wileycom.ezproxy.lib.ucalgary.ca/doi/epdf/10.1111/j.13652648.2011.05627.x

Whittemore R, \& Knafl K. (2005). The integrative review: updated methodology. Journal of Advanced Nursing (Wiley-Blackwell), 52(5), 546-553. https://onlinelibrarywiley-com.ezproxy.lib.ucalgary.ca/doi/epdf/10.1111/j.13652648.2005.03621.x 


\section{Appendix A}

\section{Extraction Tables for the Barriers Identified in 14 Articles Categorized Using the Socio- Ecological Models}

\begin{tabular}{|c|c|c|c|c|}
\hline & & \multicolumn{3}{|c|}{ Barriers } \\
\hline $\begin{array}{c}\text { Author (year), } \\
\text { Country } \\
\text { Focus }\end{array}$ & $\begin{array}{c}\text { Methodology } \\
\text { Design, Sample, } \\
\text { Data Collection } \\
\text { \& Analyses } \\
\end{array}$ & Individual & $\begin{array}{l}\text { Organizational, Social, } \\
\text { Cultural \& Policy }\end{array}$ & Environment \\
\hline $\begin{array}{l}\text { Poghosyan, et } \\
\text { al., (2013) } \\
\text { USA } \\
\text { Facilitators and } \\
\text { Barriers for } \\
\text { Primary Care } \\
\text { Nurse } \\
\text { Practitioners }\end{array}$ & $\begin{array}{l}\text { Design: } \\
\text { Qualitative } \\
\text { descriptive } \\
\text { Sample: } \\
\text { Purposive } \\
\text { sampling- } 23 \text { NPs } \\
\text { Data Collection: } \\
\text { 1. group interview } \\
\text { guide developed } \\
\text { by authors ( } n=7 \text { ) } \\
\text { 2. individual } \\
\text { interview guide } \\
\text { used ( } n=16) \\
\text { Data Analyses: } \\
\text { Thematic analysis }\end{array}$ & $\begin{array}{l}\text { Comprebension of NP } \\
\text { role: administrators, } \\
\text { physician, staff, and } \\
\text { patients did not have } \\
\text { clear understanding of } \\
\text { NP role and Scope of } \\
\text { practice. }\end{array}$ & $\begin{array}{l}\text { Getting to know the } \\
\text { patient hindered by } \\
\text { organizational processes } \\
\text { related to patient } \\
\text { scheduling. Challenging } \\
\text { to care for patients on a } \\
\text { shifting basis. } \\
\text { There is no NP's patient } \\
\text { panel } \\
\text { NP role in some clinics } \\
\text { not clearly defined. } \\
\text { NP and did not receive } \\
\text { assistance from medical } \\
\text { assistants or other nurses } \\
\text { Stressorin workplace: } \\
\text { General stressors -lack } \\
\text { patient-care support, lack } \\
\text { of access to medical } \\
\text { organizational supports, } \\
\text { poor relations with some } \\
\text { physicians and practice } \\
\text { administration \& little or } \\
\text { no representation of NP } \\
\text { involvement in decision- } \\
\text { making \& no one to } \\
\text { advocate the creation of } \\
\text { organizational structure } \\
\text { to promote Scope of } \\
\text { Practice for NP } \\
\text { regulations require } \\
\text { supervision by physician } \\
\text { NP has to wait for } \\
\text { doctors to sign off } \\
\text { Organization forced to } \\
\text { conplete forms to } \\
\text { maximize reimbursement } \\
\text { rather than tracks who } \\
\text { provided care. Policies } \\
\text { and billing practices main } \\
\text { challenges. } \\
\text { Only one primary care } \\
\text { person could be listed in } \\
\text { chart. }\end{array}$ & \\
\hline $\begin{array}{l}\text { Steinke et al., } \\
\text { (2017) }\end{array}$ & $\begin{array}{l}\text { Design: } \\
\text { quantitative - } \\
\text { Cross sectional }\end{array}$ & $\begin{array}{l}\text { Lack of support from } \\
\text { nursing colleagues } \\
\text { (colleagues may feel }\end{array}$ & $\begin{array}{l}\text { Key barrier lack of } \\
\text { respect from supervisors } \\
\text { and physicians }\end{array}$ & \\
\hline
\end{tabular}




\begin{tabular}{|c|c|c|c|}
\hline $\begin{array}{l}\text { To examine job } \\
\text { satisfaction } \\
\text { among NP \& } \\
\text { APNs in } \\
\text { developing } \\
\text { and developed } \\
\text { countries, and to } \\
\text { provide insight } \\
\text { re the barriers } \\
\text { and facilitators } \\
\text { for NP and APN. } \\
\text { The quantitative } \\
\text { results will not } \\
\text { be presented } \\
\text { because this } \\
\text { survey measures } \\
\text { job satisfaction } \\
\text { primarily. } \\
\text { However the } \\
\text { authors did } \\
\text { capture some } \\
\text { insights about } \\
\text { the barriers in } \\
\text { the open-ended } \\
\text { questions at the } \\
\text { end of the } \\
\text { survey. }\end{array}$ & $\begin{array}{l}\text { descriptive } \\
\text { Sample: } \\
\text { Purposive } \\
\text { sampling } \\
1680 \text { completed } \\
\text { the survey, } \\
\text { N=1419survey } \\
\text { analyzed, } 85 \% \\
\text { female, } 60 \% \\
\text { between } 42-60 \\
\text { years, most } \\
\text { practiced less than } \\
6 \text { years. } \\
\text { Participants from } \\
19 \text { coumtries. } \\
\text { Data Collection: } \\
\text { Invitations sent } \\
\text { via ICN nurses } \\
\text { Survey tool } \\
\text { (modified } \\
\text { Misener Nurse } \\
\text { Practitioner Job } \\
\text { Satisfaction Scale } \\
\text { (MNPJSS) had } \\
\text { some open-ended } \\
\text { questions } \\
\text { Data Analyses: } \\
\text { Thematic analysis } \\
\text { Also did linear } \\
\text { regression for } \\
\text { quantitative data }\end{array}$ & $\begin{array}{l}\text { threatened by emerging } \\
\text { of APN roles) }\end{array}$ & $\begin{array}{l}\text { Management not } \\
\text { accepting APN. } \\
\text { Lack of dual role position } \\
\text { (e.g. teaching at } \\
\text { university and having a } \\
\text { practice. } \\
\text { Lack of support for } \\
\text { obtaining doctorate } \\
\text { degree) } \\
\text { Increase in administrative } \\
\text { tasks which decreased } \\
\text { patient contact and } \\
\text { increased workload } \\
\text { Lack of vacation pay, } \\
\text { retirement and leave } \\
\text { policies }\end{array}$ \\
\hline $\begin{array}{l}\text { Chapman et al, } \\
2018 \\
\text { California } \\
\text { To describe bow } \\
\text { PMHNPs } \\
\text { utilization, } \\
\text { identify barriers } \\
\text { to full } \\
\text { utilization, and } \\
\text { assess PMHNPs' } \\
\text { economic } \\
\text { contribution in } \\
\text { public } \\
\text { behavioral bealth } \\
\text { systems. } \\
\text { Legend: } \\
\text { Psychiatric } \\
\text { Mental Health } \\
\text { Nurse } \\
\text { Practitioners } \\
\text { =(PMHNPs) }\end{array}$ & $\begin{array}{l}\text { Design: Mixed } \\
\text { method } \\
\text { Sample: } \\
\text { Convenience } \\
\text { sample of mental } \\
\text { health \& medical } \\
\text { directors, } \\
\text { PMHNPs, } \\
\text { Managers (ie. } \\
\text { HR, quality, } \\
\text { finances \& } \\
\text { billing) } \\
\text { Data Collection: } \\
\text { Semi-structured } \\
\text { interviews (in } \\
\text { person \& over } \\
\text { phone) } \\
\text { Data Analyses: } \\
\text { Thematic analysis } \\
\text { Quantitative - } \\
\text { Data on billing } \\
\text { and finances } \\
\text { collected and } \\
\text { analyzed }\end{array}$ & & $\begin{array}{l}\text { Lack of appropriate job } \\
\text { descriptions } \\
\text { lack of coumty-approved } \\
\text { open positions for the } \\
\text { role } \\
\text { Lengthy civil service } \\
\text { processes for hiring } \\
\text { PMHNPs in contract } \\
\text { position expressed } \\
\text { dissatisfaction of not } \\
\text { receiving benefits that } \\
\text { psychiatrists receive) } \\
\text { Health directors did not } \\
\text { understand the details of } \\
\text { NP supervision } \\
\text { Psychiatrists refusing to } \\
\text { supervise PMHNPs } \\
\text { Restricted scope of } \\
\text { practice for NPs in } \\
\text { Califormia (law requires } \\
\text { MD supervision) }\end{array}$ \\
\hline $\begin{array}{l}\text { Sharp \& } \\
\text { Monsivais, } 2014 \\
\text { Texas }\end{array}$ & $\begin{array}{l}\text { Design: } \\
\text { qualitative } \\
\text { Ethnography } \\
\text { Sample: }\end{array}$ & $\begin{array}{l}\text { Lack of business skills } \\
\text { and knowledge needed } \\
\text { to manage clinic } \\
\text { ownership. }\end{array}$ & $\begin{array}{l}\text { NP clinic continue to } \\
\text { depend on private pay } \\
\text { patients, third person } \\
\text { payment, and other }\end{array}$ \\
\hline
\end{tabular}




\begin{tabular}{|c|c|c|c|}
\hline $\begin{array}{l}\text { To describe } \\
\text { difficulties } \\
\text { related to the } \\
\text { business-related } \\
\text { aspects of } \\
\text { practice in role } \\
\text { transition of } \\
\text { rural (NPs), and } \\
\text { to provide } \\
\text { implications for } \\
\text { practice. } \\
\text { Conceptual } \\
\text { framework: } \\
\text { developed by } \\
\text { Sharp (2010) }\end{array}$ & $\begin{array}{l}24 \text { rural NPs, } \\
\text { female } 93 \%, 51 \text { - } \\
60 \text { years old, over } \\
20 \text { years of } \\
\text { practice } \\
\text { recruited from the } \\
\text { National Health } \\
\text { Service Corps } \\
\text { Database. } \\
\text { Data Collection: } \\
\text { Semi-structured } \\
\text { interviews } \\
\text { Data Analyses: } \\
\text { Constant } \\
\text { comparison } \\
\text { analyses } \\
3 \text { main themes: } \\
\text { Scope of practice, } \\
\text { business skills, \& } \\
\text { role conflict }\end{array}$ & $\begin{array}{l}\text { Role conflict } \\
\text { experienced between } \\
\text { taking care of patients } \\
\text { and managing the } \\
\text { clinical practice. } \\
\text { Anxiety, uncertainty, } \\
\text { stress during transition. }\end{array}$ & $\begin{array}{l}\text { government funding. } \\
\text { Some states permit NPs } \\
\text { to practice independently, } \\
\text { others require the } \\
\text { supervision or } \\
\text { collaboration of a } \\
\text { physician. } \\
\text { NP underutilized because } \\
\text { of state nursing acts. } \\
\text { Reimbursement for NP } \\
\text { differ from physicians } \\
\text { resulting in decreased } \\
\text { income }\end{array}$ \\
\hline $\begin{array}{l}\text { Kraus \& Dubois, } \\
2016 \\
\text { USA } \\
\text { To explore the } \\
\text { attitudes of NP } \\
\text { \& physicians } \\
\text { related to the } \\
\text { independent } \\
\text { practice of NP }\end{array}$ & $\begin{array}{l}\text { Design: } \\
\text { Qualitative } \\
\text { grounded theory } \\
\text { Sample: } \\
\text { Purposive } \\
\text { sampling } 15 \\
\text { physicians \& } 15 \\
\text { NPs working in } \\
\text { academic and } \\
\text { private primary } \\
\text { care } \\
\text { Data Collection: } \\
\text { Semi-structured } \\
\text { in-depth } \\
\text { interviews } \\
\text { Data Analyses: } \\
\text { Constant } \\
\text { comparison- led } \\
\text { to themes and } \\
\text { interpretations }\end{array}$ & $\begin{array}{l}\text { For physicians' caveats } \\
\text { included knowing your } \\
\text { limits, experience and } \\
\text { training "NP should } \\
\text { know when to ask } \\
\text { questions" } \\
\text { Most physicians insisted } \\
\text { on some degree of } \\
\text { supervision to ensure } \\
\text { patient safety, given } \\
\text { perceived gap in NP } \\
\text { training Both groups } \\
\text { Both groups rejected the } \\
\text { idea that the physician } \\
\text { must be a bovering } \\
\text { presence to ensure good } \\
\text { care quality. }\end{array}$ & $\begin{array}{l}\text { Barriers to independence: } \\
\text { Physicians focus on NP } \\
\text { independence was very } \\
\text { patient- oriented and not } \\
\text { self-promoting or defiant. } \\
\text { Physicians less } \\
\text { frequently than NP } \\
\text { referenced laws that did } \\
\text { not seem reasonable and } \\
\text { did not optimized NP } \\
\text { ability to provide the care } \\
\text { they saw as part of their } \\
\text { SOP. } \\
\text { NP also slimily } \\
\text { referenced arbitrary laws } \\
\text { and practice restrictions } \\
\text { that seemed unreasonable } \\
\text { for safe and efficient } \\
\text { care. }\end{array}$ \\
\hline $\begin{array}{l}\text { Guzman, } \\
\text { Ciliska, \& } \\
\text { DiCenso (2010), } \\
\text { Ontario Canada } \\
\text { To identify } \\
\text { barriers and } \\
\text { facilitators } \\
\text { associated with } \\
\text { the } \\
\text { implementation } \\
\text { of the NPs role } \\
\text { in Ontario's } \\
\text { public health } \\
\text { units, \& NPs' } \\
\text { job satisfaction- } \\
\text { and the } \\
\text { relationship }\end{array}$ & $\begin{array}{l}\text { Design: } \\
\text { Quantitative } \\
\text { Descriptive } \\
\text { Sample: } \\
28 \text { NPs working } \\
\text { in } 36 \text { Ontario } \\
\text { public health units } \\
\text { (96.5\% response } \\
\text { rate) } \\
\text { Female, } 36-45 \\
\text { years of age, } \\
\text { BScN degree and } \\
\text { post- } \\
\text { baccalaureate NP } \\
\text { Data Collection: } \\
\text { postal survey } \\
\text { Data Analyses: } \\
\text { Descriptive }\end{array}$ & $\begin{array}{l}\text { Response to short } \\
\text { answer questions } \\
\text { Themes to emerge was } \\
\text { "related to professional } \\
\text { isolation" ( } 25 \%), 3.6 \% \\
\text { working on their own, \& } \\
\text { not being part of team } \\
27 \% \\
\text { Most frequent barriers } \\
\text { specific to the } \\
\text { relationship between } \\
\text { NPs \& physician were: } \\
\text { unwillingness of } \\
\text { specialists to accept } \\
\text { referrals from NPs } \\
\text { (53.5\%), physician lack } \\
\text { of understanding of the }\end{array}$ & $\begin{array}{l}\text { Percentage who ranked } \\
\text { barriers as the top ranked } \\
\text { barrier } \\
39.2 \% \text { being only NP } \\
\text { working in unit. } \\
32.1 \% \text { salary of NP } \\
32.1 \% \text { employer } \\
\text { knowledge of NP role } \\
28.5 \% \text { time travelling } \\
\text { home to practice } \\
21.2 \% \text { employer support } \\
\text { of NP role } \\
14.2 \% \text { receiving clerical } \\
\text { support } \\
14.2 \% \text { dealing with } \\
\text { client's complex social } \\
\text { issues } \\
10.7 \% \text { NP coverage }\end{array}$ \\
\hline
\end{tabular}




\begin{tabular}{|c|c|c|c|}
\hline $\begin{array}{l}\text { between NP job } \\
\text { satisfaction and } \\
\text { practice } \\
\text { dimension }\end{array}$ & $\begin{array}{l}\text { statistics \& } \\
\text { several survey } \\
\text { questions required } \\
\text { short answers, } \\
\text { authors coded } \\
\text { themes }\end{array}$ & $\begin{array}{l}\text { NP role (42.8\%), the } \\
\text { personality \& } \\
\text { philosophy of the } \\
\text { physicians ( } 35.7 \% \text { ) } \\
\text { The most ranked } \\
\text { barriers related to the } \\
\text { relationship were: } \\
\text { umwillingness of } \\
\text { specialists to accept } \\
\text { referrals from NPs } \\
\text { (53.5\%), lack of respect } \\
\text { shown by the physicians } \\
\text { ( } 46.4 \% \text { ), NPs feel } \\
\text { overwhelmed by the } \\
\text { demands of their role } \\
\text { given their solitary work } \\
\text { environment, \& } \\
\text { isolation from other } \\
\text { PHU staff, \& some } \\
\text { PHU employer may } \\
\text { perceive the PHU NP } \\
\text { role to become more of } \\
\text { a physician replacement. }\end{array}$ & $\begin{array}{l}\text { (vacation or illness) } \\
10.7 \% \text { union } \\
\text { membership. } \\
7.1 \% \text { NP involvement in } \\
\text { developing NP role. } \\
3.6 \% \text { being consulted by } \\
\text { PHU staff, access to PHU } \\
\text { programs, } \\
\text { NP linkage to PHU } \\
\text { programs, working with } \\
\text { PHNs, \& support for } \\
\text { management. }\end{array}$ \\
\hline $\begin{array}{l}\text { Nasaif, H. A. } \\
\text { (2012) } \\
\text { Kingdom of } \\
\text { Bahrain } \\
\text { To examine the } \\
\text { knowledge and } \\
\text { attitude of } \\
\text { primary care } \\
\text { physicians } \\
\text { (PCPs) about the } \\
\text { NP role prior to } \\
\text { and following an } \\
\text { educational } \\
\text { intervention } \\
\text { First study in } \\
\text { Bahrain to } \\
\text { evaluate PCP } \\
\text { knowledge and } \\
\text { attitudes prior to } \\
\text { NP role } \\
\text { inplementation. }\end{array}$ & $\begin{array}{l}\text { Design: } \\
\text { quantitative } \\
\text { Quasi- } \\
\text { experimental } \\
\text { Sample: } \\
\text { Nonprobability } \\
\text { convenience } \\
\text { sample } \\
\text { N=90 PCPs (27- } \\
63 \text { yrs.), majority } \\
\text { female, from } 12 \\
\text { health centers. } \\
\text { Educational } \\
\text { intervention: two } \\
\text { DvD used } \\
\text { Data Collection: } \\
\text { Survey (modified } \\
\text { northern } \\
\text { emergency nurse } \\
\text { practitioner tool) } \\
\text { used pre- and } \\
\text { post- test } \\
\text { Data Analyses: } \\
\text { Descriptive. } \\
\text { Significant } \\
\text { difference pre \& } \\
\text { post- test } \\
\text { Knowledge mean } \\
\text { scores. }\end{array}$ & $\begin{array}{l}\text { Pre-test: lnowledge of } \\
\text { PCPs about NP role: } \\
85.3 \% \text { had not read } \\
\text { anything about NP, } \\
46.7 \% \text { had heard about } \\
\text { NP } \\
48.9 \% \text { strongly agreed, } \\
10 \% \text { disagreed that they } \\
\text { understood the role of } \\
\text { NP } \\
46.7 \% \text { strongly } \\
\text { disagreed that they } \\
\text { understood bow the NP } \\
\text { role will function. } \\
41.1 \% \text { strongly } \\
\text { disagreed, } 7.8 \% \\
\text { disagreed } \\
\text { that they understood } \\
\text { which patients are } \\
\text { suitable for management } \\
\text { by NP. } \\
43.3 \% \text { strongly } \\
\text { disagreed that they } \\
\text { understood the NP scope } \\
\text { of practice. } \\
38.9 \% \text { strongly } \\
\text { disagreed, } 11.1 \% \\
\text { disagreed } \\
\text { That they understood } \\
\text { how the NP is different } \\
\text { from an RN. } \\
44.4 \% \text { strongly }\end{array}$ & $\begin{array}{l}\text { The majority of } \\
\text { participants graduated } \\
\text { and finished their training } \\
\text { in local and regional } \\
\text { universities where the NP } \\
\text { role does not exist. }\end{array}$ \\
\hline
\end{tabular}


disagreed that they had a good understanding of bow the NP clinical practice guideline will form the basis for the primary care nurse practitioner.

$40 \%$ strongly disagree,

$33.3 \%$ no opinion, $11,1 \%$ agreed, $7.8 \%$ strongly agreed that they understood the educational preparation required to become a primary care NP.

$45.6 \%$ strongly disagree, $32.2 \%$ no opinion, $10 \%$ agreed, $6.7 \%$ strongly agreed that they understood the nursing board requirement for endorsement as an NP.

Pre-test: Attitudes of PCPs about the role of the NP

$52.5 \%$ agreed that the NP has the skill \& knowledge to provide appropriate educational for specific patient groups, \& to appropriately refer specific patient groups.

$35.6 \%$ agreed, $31.1 \%$ no opinion, $21.1 \%$ strongly disagree, $8.9 \%$ disagreed that NP has the skill to prescribe medication. $37.8 \%$ had no opinion, $26.7 \%$ strongly disagree that the NP has the skill \& knowledge to refer patient directly to outpatient specialist clinic.

$36.6 \%$ agreed, $18.9 \%$ strongly disagree, $28.9 \%$ no opinion that the NP's has the skill \& knowledge to write absence-form work certificates. 


\begin{tabular}{|c|c|c|c|c|}
\hline & & $\begin{array}{l}\text { that the NPs had the } \\
\text { ability to discharge } \\
\text { patients from bealth } \\
\text { center. } \\
42.2 \% \text { agreed that the } \\
\text { NP has the skill \& } \\
\text { knowledge to initiate } \\
\text { medical diagnosis. } \\
34.4 \% \text { strongly disagree, } \\
31.1 \% \text { had no opinion } \\
\text { that they had no skill } \\
\text { and knowledge to refer a } \\
\text { patient directly for } \\
\text { admission as an in- } \\
\text { patient. } \\
51.1 \% \text { agreed, } 25.6 \% \\
\text { strongly agreed that the } \\
\text { NP will make primary } \\
\text { care more effective } \\
54.4 \% \text { agreed, } 23.3 \% \\
\text { strongly agreed that the } \\
\text { NP will improve access } \\
\text { to primary care health } \\
\text { 5ervices in the } \\
\text { Kingdome of Bahrain }\end{array}$ & & \\
\hline $\begin{array}{l}\text { Poghosyan, et } \\
\text { al., } 2017 \\
\text { USA } \\
\text { To examine and } \\
\text { compare the NP } \\
\text { patient panel, job } \\
\text { satisfaction, } \\
\text { turnover } \\
\text { intentions, \& } \\
\text { organizational } \\
\text { structures within } \\
\text { the employment } \\
\text { settings of NPs } \\
\text { with less than } \\
\text { three (newly } \\
\text { hired) versus } \\
\text { those with more } \\
\text { than three years } \\
\text { of NP } \\
\text { experience. }\end{array}$ & $\begin{array}{l}\text { Design: } \\
\text { quantitative } \\
\text { Cross-sectional } \\
\text { descriptive } \\
\text { Sample: } \\
\text { N= } 342 \text { NPs } \\
\text { accessed the } \\
\text { survey, } \\
64 \text { NPs not } \\
\text { practicing in } \\
\text { primary care } \\
\text { and } 278 \text { NPs } \\
\text { completed survey. } \\
\text { (n= } 98 \text { new hired, } \\
\text { 147 experienced) } \\
\text { From adult, } \\
\text { family, pediatric, } \\
\text { women's health, } \\
\text { and gerontology } \\
\text { settings } \\
\text { Data Collection: } \\
\text { online survey } \\
\text { Data Analyses: } \\
\text { four- point Likert } \\
\text { scale } \\
\text { job satisfaction } \\
\text { (intentions of } \\
\text { leaving their job) } \\
\text { and } \\
\text { Organizational } \\
\text { structure (1.e. } \\
\text { relationship with }\end{array}$ & $\begin{array}{l}\text { Overall results: } 29 \% \text { of } \\
\text { both newly hires \& } \\
\text { experienced NPs } \\
\text { reported job dissatisfied } \\
\& 25.5 \% \text { of new hires \& } \\
14.3 \% \text { of experienced } \\
\text { NPs planned to leave } \\
\text { jobs ( } p=.03 \text { ). } \\
\text { Group differences: } \\
\text { Role and organizational } \\
\text { governance (only } \\
\text { significant groups } \\
\text { differences were } \\
\text { reported in this table) } \\
\text { A significantly greater } \\
\text { new hires ( } 42.9 \% \text { vs } \\
27.9 \% \text { experienced NP } \\
\text { disagreed that NP role is } \\
\text { understood ( } p=.02 \text { ) } \\
\text { A significantly greater } \\
\text { proportion of new hires } \\
32.7 \% \text { vs } 21.1 \% \text { of } \\
\text { experienced NPs } \\
\text { disagreed that staff } \\
\text { members understood } \\
\text { role (p=.05) } \\
\text { A significantly greater } \\
\text { proportion of new hires } \\
22.4 \% \text { vs } 9.5 \% \text { of }\end{array}$ & $\begin{array}{l}53.1 \% \text { experienced NPs } \\
\text { and } 41.1 \% \text { reported } \\
\text { having their own patient } \\
\text { panel } \\
\text { Almost half of NPs } \\
\text { reported that NPs are not } \\
\text { represented in important } \\
\text { committees with their } \\
\text { organizations. } \\
30 \% \text { of newly hired and } \\
\text { experienced NPs reported } \\
\text { a lack of ancillary staff to } \\
\text { prepare patients (e.g. } \\
\text { height/ weight) during } \\
\text { the visits. } \\
\text { NPs in each group } \\
\text { reported lacking adequate } \\
\text { time during patient's } \\
\text { visits. } \\
38 \% \text { of new hires vs } \\
30.6 \% \text { of experienced } \\
\text { NPs reported not } \\
\text { receiving feedback about } \\
\text { their performance. } \\
36.7 \% \text { of new hires vs } \\
26.5 \% \text { of experienced } \\
\text { NPs reported not being }\end{array}$ & \\
\hline
\end{tabular}




\begin{tabular}{|c|c|c|c|}
\hline & $\begin{array}{l}\text { physician and } \\
\text { administrators, } \\
\text { support, and the } \\
\text { infrastructure for } \\
\text { care delivery) }\end{array}$ & $\begin{array}{l}\text { experienced NPs } \\
\text { disagreed that patients } \\
\text { understand the role } \\
(p=.01) \\
\text { Relation with } \\
\text { physicians: } \\
\text { Overall most of NP } \\
\text { reported that physicians } \\
\text { trusted their care } \\
\text { decisions } \\
\text { A significantly greater } \\
\text { proportion of new hired } \\
\text { (33.7\%) vs (20.4\%) of } \\
\text { experienced NP } \\
\text { disagreed that } \\
\text { physicians may ask for } \\
\text { advice (p=0.2) } \\
\text { A significantly larger } \\
\text { proportion of newly } \\
\text { hired NPs ( } 7.1 \% \text { ) v5 } \\
\text { (1.4\%) of experienced } \\
\text { NP disagreed with the } \\
\text { statement that } \\
\text { physicians trust NPs } \\
\text { care decisions. } \\
\text { Relations with } \\
\text { administration- no } \\
\text { Significant group } \\
\text { differences): } \\
\text { Majority of experienced } \\
\text { and new hires disagree } \\
\text { that administrators treat } \\
\text { NP and physician } \\
\text { equally. } \\
\text { Large proportion of } \\
\text { newly and experienced } \\
\text { hired NPs are } \\
\text { dissatisfied with their } \\
\text { jobs }\end{array}$ & $\begin{array}{l}\text { able to review outcome } \\
\text { measures of their care. } \\
\text { Both new hires \& } \\
\text { experienced NPs reported } \\
\text { lack of NP involvement } \\
\text { in organization } \\
\text { governance. } \\
\text { A significant challenge } \\
\text { observed in the } \\
\text { relationship between NPs } \\
\text { and administrators. } \\
\text { Administrators did not } \\
\text { view NPs equal to other } \\
\text { providers \& did not share } \\
\text { organizational resources } \\
\text { equally between these } \\
\text { providers. }\end{array}$ \\
\hline $\begin{array}{l}\text { Hernandez \& } \\
\text { Anderson, } 2011 \\
\text { USA } \\
\text { To explore the } \\
\text { NP experience } \\
\text { caring for } \\
\text { prehypertensive } \\
\text { patients }\end{array}$ & $\begin{array}{l}\text { Design: } \\
\text { qualitative, } \\
\text { Narrative inquiry } \\
\text { Sample: } \\
\text { Purposive, } \\
\text { N= } 8 \mathrm{NPs} \text { ( } 5 \\
\text { males, } 3 \text { female) } \\
\text { age } 31-53 \text { yrs. all } \\
\text { Master prepared } \\
\text { family NPs with } 4 \\
\text { months and } 18 \\
\text { years of practice } \\
\text { experience. caring } \\
\text { for } \\
\text { prehypertensive } \\
\text { patients in } \\
\text { primary care. }\end{array}$ & $\begin{array}{l}3 \text { themes emerged } \\
\text { 1-Realities of practice } \\
\text { difficult transitions due } \\
\text { to the fast-paced } \\
\text { managed health care } \\
\text { Lack of time (e.g. did } \\
\text { not prioritize health } \\
\text { promotion into patient's } \\
\text { visit) } \\
\text { 2-Ambiguous role } \\
\text { identity } \\
\text { Disconnect between } \\
\text { actual practice \& model } \\
\text { used in school } \\
\text { (socialization nursing } \\
\text { model) }\end{array}$ & $\begin{array}{l}\text { Realities of practice } \\
\text { Time constraints \& } \\
\text { financial considerations } \\
\text { such as billing for } \\
\text { healthcare services } \\
\text { Lack of public support } \\
\text { for bealth promotion } \\
\text { activities. } \\
\text { Daily pressure of tight } \\
\text { schedules, double } \\
\text { booking of patients, and } \\
\text { coordinating care with } \\
\text { ancillary bealthcare } \\
\text { services often led to a } \\
\text { sense of just "surviving }\end{array}$ \\
\hline
\end{tabular}




\begin{tabular}{|c|c|c|c|c|}
\hline & $\begin{array}{l}\text { Data Collection: } \\
\text { Semi-structured } \\
\text { Interviews } \\
\text { (initial conducted } \\
\text { face to face, } \\
\text { follow up } \\
\text { conducted by } \\
\text { phone } \\
\text { audio recorded) } \\
\text { Data Analyses: } \\
\text { Thematic analysis }\end{array}$ & $\begin{array}{l}\text { Difficulty connecting } \\
\text { medical \& preventative } \\
\text { care model } \\
\text { 3-Bridging medical } \\
\text { and nursing models } \\
\text { Patients' unwillinguess } \\
\text { to take health promotion } \\
\text { seriously, lack of } \\
\text { commitment } \\
\text { NPs dealt with mounting } \\
\text { feelings of helplessness. }\end{array}$ & $\begin{array}{l}\text { the day" } \\
\text { Lack of public support } \\
\text { for bealth promotion } \\
\text { activities }\end{array}$ & \\
\hline $\begin{array}{l}\text { Voogdt-Pruis et } \\
\text { al. (2011) } \\
\text { Netherlands } \\
\text { To examine the } \\
\text { experiences } \\
\text { (barriers and } \\
\text { facilitators) of } \\
\text { general } \\
\text { practitioners and } \\
\text { practice nurses } \\
\text { inplementing } \\
\text { nurse-delivered } \\
\text { cardiovascular } \\
\text { prevention in } \\
\text { primary care }\end{array}$ & $\begin{array}{l}\text { Design: } \\
\text { qualitative study } \\
\text { nested in a RCT. } \\
\text { Sample: } \\
1^{*} \text { interviews } \\
\mathrm{N}=6 \text { practice } \\
\text { nurses } \\
2^{\text {al }} \text { interviews } \\
6 \text { GPs \& } 6 \text { general } \\
\text { practice nurses } \\
\text { (Nurses asked to } \\
\text { write down their } \\
\text { experiences and } \\
\text { then to discuss in } \\
\text { Focus groups) } \\
\text { Data Collection: } \\
\text { first focus group } \\
\text { then semi- } \\
\text { structured } \\
\text { individual } \\
\text { interviews } \\
\text { (overlapping } \\
\text { interview guide- } 1 \\
\text { for GPs \& one for } \\
\text { nurses), } \\
\text { Data Analyses: } \\
\text { Context analyses }\end{array}$ & $\begin{array}{l}\text { Job description: } \\
\text { Nurses need additional } \\
\text { training. } \\
\text { Fear of losing some } \\
\text { nursing tasks. } \\
\text { Guideline: } \\
\text { Lack of knowledge } \\
\text { about guidelines for } \\
\text { prevention of } \\
\text { Cardiovascular Disease } \\
\text { (CD). } \\
\text { GPs commented that } \\
\text { some of the nurses are } \\
\text { not really trained on } \\
\text { counselling. } \\
\text { Communication: } \\
\text { Lack of communication } \\
\text { among GPs \& nurses } \\
\text { about practice nurses' } \\
\text { performance. } \\
\text { Insufficient coaching by } \\
\text { doctors }\end{array}$ & $\begin{array}{l}\text { Job description: } \\
\text { GPs lack knowledge of } \\
\text { the guideline, job } \\
\text { description in shared } \\
\text { care. } \\
\text { Guideline: } \\
\text { Shared decision making } \\
\text { Equipment } \\
\text { Lack of ability to register } \\
\text { special circumstances or } \\
\text { treatment. } \\
\text { Communication: } \\
\text { Did not know who to } \\
\text { communicate with in the } \\
\text { case of a patient visiting } \\
\text { a specialist. } \\
\text { Contert: } \\
\text { Limited patient recording } \\
\text { \& computer systems } \\
\text { Clinic work hours } \\
\text { Workload } \\
\text { Poor patient recording }\end{array}$ & $\begin{array}{l}\text { Contert: } \\
\text { Lack of } \\
\text { physical space }\end{array}$ \\
\hline $\begin{array}{l}\text { Henni et al, } \\
2018 \\
\text { Norway } \\
\text { To describe the } \\
\text { experiences of } \\
\text { nurses with their } \\
\text { new role as } \\
\text { advanced } \\
\text { geriatric nurses } \\
\text { (AGN) in care } \\
\text { for older adults } \\
\text { and determine } \\
\text { what strategies } \\
\text { the nurses } \\
\text { considered } \\
\text { important in the } \\
\text { development of } \\
\text { their new role. }\end{array}$ & $\begin{array}{l}\text { Design: } \\
\text { Qualitative } \\
\text { descriptive } \\
\text { exploratory } \\
\text { Sample: Sample } \\
\mathrm{N}=21 \\
\text { AGN } \\
\text { All but one had } \\
\text { experience in } \\
\text { primary care \& all } \\
\text { had considerable } \\
\text { experience as } \\
\text { nurse before } \\
\text { becoming as } \\
\text { AGNs } \\
\text { Data Collection: } \\
\text { In depth } \\
\text { interviews } \\
\text { Data Analyses: } \\
\text { Content analysis }\end{array}$ & & $\begin{array}{l}\text { Challenging to integrate } \\
\text { \& establish a new nurse } \\
\text { role in the primary } \\
\text { healthcare system } \\
\text { Participants felt that it } \\
\text { was difficult to develop } \\
\text { role because there were } \\
\text { no formal regulations. } \\
\text { framework or guidelines } \\
\text { Lack of engagement from } \\
\text { the managers (e.g., Some } \\
\text { AGNs felt that the } \\
\text { managers had not } \\
\text { performed enough to } \\
\text { customize the AGN } \\
\text { position in a way that } \\
\text { optimized the use of } \\
\text { knowledge and skills) }\end{array}$ & \\
\hline
\end{tabular}




\begin{tabular}{|c|c|c|c|}
\hline & & $\begin{array}{l}\text { physicians \& collogues } \\
\text { were unfamiliar with the } \\
\text { AGN role at first, this } \\
\text { could lead to some } \\
\text { conflicts with diminished } \\
\text { as people worked } \\
\text { together. } \\
\text { The role of AGNs and } \\
\text { other advanced practice } \\
\text { nurses in Norway are } \\
\text { currently unknown }\end{array}$ & \\
\hline $\begin{array}{l}\text { McKenna, et al., } \\
2015 \\
\text { Australia } \\
\text { To explore } \\
\text { barriers \& } \\
\text { enablers } \\
\text { influencing the } \\
\text { development of } \\
\text { advanced } \\
\text { nursing roles in } \\
\text { general practice } \\
\text { from the } \\
\text { perspective of } \\
\text { key stakeholders } \\
\text { in primary care. }\end{array}$ & $\begin{array}{l}\text { Design: } \\
\text { Qualitative } \\
\text { exploratory (3 } \\
\text { round Delphi } \\
\text { study) } \\
\text { Sample: } \\
\mathrm{N}=23 \text { (3 nursing } \\
\text { academics, } 5 \\
\text { decision makers } \\
\text { in PHC, } 6 \\
\text { professional } \\
\text { organizations, } 4 \\
\text { senior staff, } 4 \\
\text { leading practice } \\
\text { nurses, I } \\
\text { consumer } \\
\text { advocate). } \\
\text { Data Collection: } \\
\text { semi structured } \\
\text { interview guide } \\
\text { (17 by phone and } \\
5 \text { face to face). } \\
\text { Data Analyses: } \\
\text { Thematic analysis }\end{array}$ & $\begin{array}{l}\text { Increasing awareness } \\
\text { and attractiveness of } \\
\text { nursing in general } \\
\text { practice: } \\
\text { Limited attention to } \\
\text { retention of nurses in } \\
\text { primary care. } \\
\text { Need for the } \\
\text { development of a clear } \\
\text { role definition. } \\
\text { Finding sufficiently } \\
\text { skilled nurses is a key } \\
\text { factor in managing } \\
\text { existing nursing } \\
\text { workload. } \\
\text { Difficulties in developing } \\
\text { clear career pathway. } \\
\text { Practice limitation: } \\
\text { Nurses not encouraged to } \\
\text { develop roles and work } \\
\text { to their full scope of } \\
\text { practice, many become } \\
\text { frustrated and left their } \\
\text { specialty. } \\
\text { Lack of peer support and } \\
\text { management support. } \\
\text { Nurses feels frustrated } \\
\text { being unable to influence } \\
\text { care delivery models. } \\
\text { Not having the time to } \\
\text { undertake advanced care } \\
\text { focused activities, (e.g. } \\
\text { evaluation of care } \\
\text { outcomes) } \\
\text { Emphasis on business } \\
\text { model rather than nursing } \\
\text { service. } \\
\text { Education and } \\
\text { professional } \\
\text { development factors: } \\
\text { Lack of access (e.g. } \\
\text { difficulty in finding } \\
\text { replacement nurses) and } \\
\text { funding to appropriate } \\
\text { education (e.g. basic PD } \\
\text { and post graduate } \\
\text { education). Current } \\
\text { education focused in }\end{array}$ & $\begin{array}{l}\text { No designed } \\
\text { work spaces } \\
\text { due to lack of } \\
\text { funding. } \\
\text { Nurses } \\
\text { frequently } \\
\text { used treatment } \\
\text { rooms or desk } \\
\text { in corridors. }\end{array}$ \\
\hline
\end{tabular}




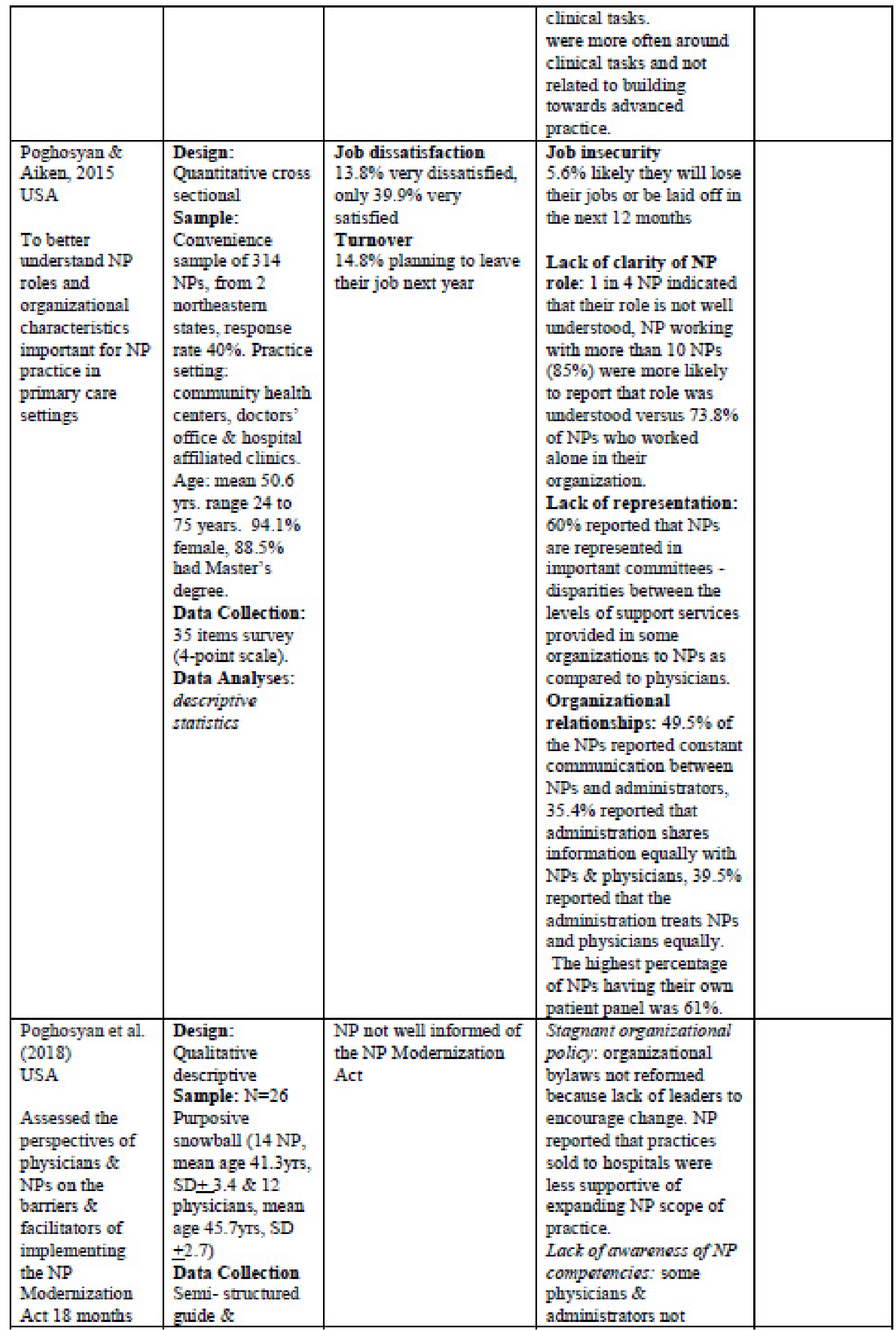




\begin{tabular}{|l|l|l|}
\hline $\begin{array}{l}\text { after the policy } \\
\text { adaption. }\end{array}$ & $\begin{array}{l}\text { individual } \\
\text { interviews } \\
\text { Data Analyses: } \\
\text { Thematic } \\
\text { analyses }\end{array}$ & $\begin{array}{l}\text { familiar with the care } \\
\text { NPs can deliver or their } \\
\text { competencies. } \\
\text { Physician perceived that } \\
\text { NPs competencies are not } \\
\text { generalizable to the } \\
\text { overall NP workforce. } \\
\text { Lack of knowiodge about } \\
\text { the NP Modornization } \\
\text { Act: few physicians } \\
\text { aware about Act. Both } \\
\text { NPs \& physicians } \\
\text { reported that their } \\
\text { organization do not keep } \\
\text { informed about the state } \\
\text { policy change. } \\
\end{array}$ \\
& $\begin{array}{l}\text { Physician autonomy and } \\
\text { resistance to change: two } \\
\text { physicians reported } \\
\text { resistant to surrender } \\
\text { some of their rights }\end{array}$ \\
\hline
\end{tabular}

